\title{
PENGARUH GAME ONLINE TERHADAP PSIKOLOGI REMAJA
}

Stepanuston Pelawi ${ }^{1}$, Stimson Hutagalung ${ }^{2}$, Rolyana Ferinia ${ }^{3}$

Universitas Advent Indonesia Bandung

sembiringstepanus05@gmail.com, stimson.hutagalung@unai.edu, rolyana.pintauli@unai.edu

\section{Abstract}

During the Covid-19 pandemic, the use of cellphones among teenagers increased rapidly both for learning and daily needs. The increase in the use of cellphones will have an impact on the lifestyle of teenagers because they play online games. Therefore, this study aims to analyze the impact of online gaming among teenagers during the Covid-19 pandemic. As the basis of this research based on Proverbs 4:23. This study uses qualitative and descriptive methods by means of analysis and interviews as well as observations to several students at the Barusjulu Adventist Junior High School. The results of the analysis and interviews and observations show that the influence of online games is very influential on the development and growth of adolescents because online games affect the health, psychological, academic, social and financial of adolescents. The implication of the results of this study, the authors suggest that parents play a role in helping and guiding their children to divide their time in playing online games. In addition, Christian Religion Teachers also have a role in guiding the youth of the Barusjulu Adventist Junior High School to increase their spiritual growth.

Keywords: Online games, Psychology, Youth

\section{Abstrak}

Selama pandemi Covid-19, penggunaan handphone di kalangan remaja meningkat pesat baik untuk pembelajaran maupun keperluan sehari-hari. Peningkatan penggunaan handphone akan berdampak pada pola kehidupan remaja karena bermain game online. Karena itu, penelitian ini bertujuan untuk menganalisis dampak game online dikalangan remaja selama pandemi Covid-19. Sebagai landasan penelitian ini berdasarkan Amsal 4:23. Penelitian ini menggunakan metode kualitatif dan deskriptif dengan cara analisis dan wawancara serta observasi kepada beberapa siswa di SMP Advent Barusjulu. Hasil analisis wawancara serta observasi menunjukkan bahwa pengaruh dari game online sangat berpengaruh terhadap perkembangan dan pertumbuhan anak remaja karena game online mempengaruhi kesehatan, psikologis, akademik, sosial dan keuangan anak remaja . Implikasi dari hasil penelitian ini, penulis menyarankan agar orang tua berperan dalam menolong dan membimbing anak-anak mereka membagi waktu dalam bermain game online . Selain itu, Guru Agama Kristen juga memiliki perananan dalam membimbing remaja SMP Advent Barusjulu untuk meningkatkan pertumbuhan kerohanian mereka.

Kata Kunci: Game online, Psikologi, Remaja. 


\section{PENDAHULUAN}

Perkembangan Ilmu Pengetahuan khususnya di bidang teknologi komunikasi berkembang dengan sangat pesat. Dengan bertambahnya alat komunikasi khususnya handphone dengan berbagai merek yang diperkenalkan kepada masyarakat yang dilengkapai dengan berbagai aplikasi yang canggih yang sudah dimasukkan ke dalam handphone, salah satunya adalah aplikasi play store yang memudahkan pengguna handphone untuk mengunduh berbagai aplikasi yang dia ingin gunakan dalam handphonenya.Dengan adanya pandemi Covid-19 anak remaja dituntut untuk memiliki handphone yang dapat digunakan untuk belajar secara daring (dalam jaringan) karena pertemuan secara tatap muka tidak dapat dilakukan. Tetapi kenyataannya, sebagian besar anak remaja tidak menggunakan handphone yang telah diberikan orang tua untuk belajar, tetapi mereka gunakan untuk bermain game baik secara online maupun offline.

Permainan secara online pertama sekali digunakan di dunia militer, permainan yang dirancang adalah permainan simulasi perang ataupun pesawat yang semuanya dipergunakan untuk keperluan militer. Tetapi karena mereka meihat adanya peluang bisnis maka diperkenalkan kepada umum sehingga permainan game terus berkembang sehingga banyak game online yang muncul.

Dengan adanya game telah membawa dampak yang besar bagi seorang remaja, mereka dapat lupa waktu untuk menyelesaikan pekerjaan rumah bahkan untuk makan dan minum mereka lupa karena terlalu asik dalam bermain game, mereka menjadi candu dalam memaikan satu permainan yang berakibat adanya penurunan terhadap hasil pencapaian belajar karena waktu yang seharusnya mereka gunakan untuk belajar merekan manfaatkan untuk bermain game.

Bahkan secara psikologis pikiran mereka tergangu karena terus-menerus memikirkan bagaimana memenangkan satu permainan yang mereka telah mainkan, yang mempengaruhi tingkah laku karena apa yang mereka lihat secara terus menerus akan memjadi karekter mereka. ${ }^{1}$ Dalam hubungan sosial adanya kerenggangan antara teman dan keluarga karena waktu bersama tidak digunakan lagi untuk bercengkrama satu dengan yang lain tetapi digunakan untuk berkomunikasi kepada yang berjauhan sedangkan untuk keluarga terdekat tidak ada komunikasi.

Secara kesehatan. Pengaruh cahaya dari radiasi hanphon dapat mempengaruhi saraf mata dan otak jika digunakan terus menerus tanpa terkontrol membuat mata akan menjadi sayu. Kesehatan jantung merek juga akan terganggu karena bermain game akan membuat kurangnya waktu untuk beristirahat karena mereka hanya focus untuk bermain dan menyelesaikan satu permainan. ${ }^{2}$ Ginjal dan perut mereka juga akan terganggu karena kurangnya pergerakan dimana mereka hanya duduk tanpa bergerak dalam bermain game

\footnotetext{
${ }^{1}$ Janes Sinaga et al., "Peran Fundamental Gembala Bagi Guru Saat Pandemik Dalam Pembelajaran Online Berbasis Karakter: Tantangan Dan Sistem Pendukung," Jurnal Pendidikan Agama Kristen (JUPAK) 2, no. 1 (December 3, 2021): 13-35, accessed December 10, 2021, https://ejurnal.sttkadesiyogyakarta.ac.id/index.php/jupak/article/view/61.

${ }^{2}$ M. Th Dr. Sri Wahyuni, "PSIKOLOGI REMAJA: PENANGGULANGAN KENAKALAN REMAJA - Dr. Sri Wahyuni, M. Th - Google Books,” accessed September 29, 2021, https://books.google.co.id/books?hl=en\&lr=\&id=QGtAEAAAQBAJ\&oi=fnd\&pg=PA1\&dq=psikologi+remaj a\&ots=pgINM3QYGd\&sig=K3_FO9IDJUJUa-qsYmcFvfsUM5A\&redir_esc=y\#v=onepage\&q=psikologi remaja $\& \mathrm{f}=$ false.
} 
karena mereka sudah focus mereka lupa untuk minum, lupa makan karena mereka takut jika mereka tinggalkan permainan game akan mengalami kekalahan.

Hal tersebut juga terjadi di lingkungan SMP Swasta Advent Barusjulu. Sebelum masa pandemik covid-19, remaja yang bersekolah melakukan tugas mereka dengan baik dan yang tidak mennyelesiakan tugas dengan baik kurang dari 5 orang remaja, hal ini disebebkan karena mereka kurang pahaman dalam menyelesaikan tugas. Selama pembelajaran dalam ruangan kelas ramaja dapat menikuti pelajaran dengan baik, tetapi selama pandemic covid-19 dari pengamatan yang dilakukan kepada anak remaja yang menjadi siswa/i di SMP Advent Barusjulu ditemukan lebih dari 12 orang murid yang tidak mengerjakan tugas yang telah diberikan oleh guru kepada mereka karena waktu yang semestinya mereka gunakan untuk belajar tetapi mereka gunakan untuk bermain game, terlihat juga mata mereka yang sayu pada saat belajar yang mengakibatkan mereka mengantuk dalam ruangan kelas karena waktu istirahat dimalam hari mereka gunakan untuk bermain game dan pekerjaan rumah yang sudah menjadi rutinitas sehari-hari sebelum mereka memiliki handphone sudah terbengkalai sejak adanya handphone ditangan anak remaja karena bermain game.

Secara psikologis terlihat adanya perubahan, sebelum covid-19 pada saat istirahat mereka aktif untuk bercanda gurau satu dengan yang lain dan saling menegur sapa, dari pengamatan yang dilakukan kurang dari 3 orang anak yang hanya duduk termenung mereka tidak aktif bermain satu dengan yang lain. Tetapi saat anak remaja sudah aktif menggunakan handphone dan bermain game sudah terlihat perbedaan, ada yang tidak mau bermain satu dengan yang lain hanya duduk termenung dan emosi mereka tidak stabil, terlihat pada waktu mereka diajak oleh teman-teman untuk bermain dia hanya duduk terdiam. Sikap anak yang sudah kecanduan game online akan suka melawan baik kepada guru dan juga kepada orang tua. Pada waktu orang tua melarang mereka menggunakan hanphon dan bermain game terlihat perlawanan yang diberikan anak remaja kepada orang tua mereka

Penelitian yang dilakukan ini bertujuan untuk melihat bagaimana pengaruh game online terhadap perkembangan psykologi remaja di SMP Swasta Advent Barusjulu

\section{METODE PENELITIAN}

Dalam penelitian ini menggunakan metode kualitatif ${ }^{3}$ yaitu menguraikan secara teoritis dan praktis pengaruh game online terhadap remaja dihubungkan dengan perkembangan psikologi remaja. Untuk memperjelas analisis, penelitian ini juga menggunakan obsevasi kepada anak remaja yang bersekolah di SMP Advent barusjulu dan melakukan wawancara kepada anak remaja, orang tua dan guru pengaruh yang ditimbulkan game. Untuk analisis menggunakan sumber-sumber teori dari Alkitab, jurnal, artikel dan secara deskriptif menggunakan wawancara dan observasi.

\section{HASIL DAN PEMBAHASAN}

Dalam kitab Daniel 12:4 "Tetapi engkau, Daniel sembunyikanlah segala firman itu, dan materaikanlah kitab itu sampai pada akhir zaman, banyak orang akan meyelidikinya dan pengetahuan akan bertambah". adanya kemajuan tekhnologi dijaman sekarang ini

\footnotetext{
${ }^{3}$ Ph.D Surya Dharma, MPA., "Pendekatan, Jenis, Dan Metode Penelitian Pendidikan” (2008).
} 
menunjukkan bahwa nubuatan dalam Alkitab tentang akhir zaman sudah tergenapi apalagi dengan semakin bertambahnya pengetahuan manusia untuk menciptakan alat-alat elektonik yang cangih yang diharapkan dapat menolong manusia.

Dengan kemajuan ilmu pengetahuan yang semakin meningkat dan semakain canggih, maka segala aktifitas manusia sudah bergantung kepada kecanggihan tekhnologi, dan salah satu kemajuan tersebut adalah dibidang media telekomunikasi diggital. Hanya dengan melalui sebuah alat kecil yang dapat digenggam ditangan yaitu handphon anak remaja dengan mudah mengakses apa yang mereka inginkan melalui internet akan segala informasi dalam segala bidang yang kita inging ketahui.

Selain untuk belajar dan mencari informasi yang dapat menolong anak dalam menyelesaikan tugas mereka, anak remaja juga mencari hiburan yaitu untuk bermain game dari handphone yang mereka miliki.

\section{Game}

Aplikasi permaninan game sudah ada dalam handphone android yang digunakan anak remaja. Aplikasi game yang terdapat di handphone ada yang bersifat offline dan ada yang online. Permainan geme secara offline ialah sebuah permainan yang dapat digunakan setiap waktu, sedangkan permainan geme secara online adalah satu permainan yang dapat digunakan pada saat handphone terhubung kedalan jaringan internet.

Dalam bermain game anak remaja akan lebih tertarik untuk memainkan game secara online karena banyak fitur tambahan yang dapat mereka gunakan saat bermain game, seperti lebih banyak level, aksesoris, lebih banyak lawan dalam bermain game.

Andrew Rolling dan Ernest Adam menyatakan game online merupakah sebuah teknologi yang digabungkan dengan bagaimana cara bermainnya dan juga ini merupakan satu mekasnisme agar dapat menghubungkan satu pemain dan pemain lainnya agar dapat bermain secara bersama, dibandingkan pola tertentu dalam sebuah permainan. ${ }^{4}$

Permainan game online dapat dibedakan dalam beberapa aspek:

1. Berdasarkan jenis permainannya

2. Berdasarkan cara bayarnya

3. Berdasarkan grafis

\section{Berdasarkan Jenis permainnaya}

1. Massively Multiplayer Online First-person shooter games (MMOFPS)

Game ini menggunakan pandangan orang pertama yang membuat pemain seakan-akan terlibat langsung dalam bermain permainan ini, di mana setiap tokoh memiliki kemampuan yang berbeda dalam tingkat akurasi, refleks, dan lainnya. ${ }^{5}$ Didalam memaikan permainan ini pemain merasakan seakan-akan dia terlibat langsung dalam game tersebut. Contohnya game peperangan, dimana yang terlihat hanya tangan yang memegang senjata, sehingga waktu memainkkan game tersebut sepertinya dia terlibat langsung dalam peperangan. Contoh yang lain Game balapan mobil yang terlihat hanya

\footnotetext{
4 “Permainan Daring - Wikipedia Bahasa Indonesia, Ensiklopedia Bebas," accessed November 11, 2021, https://id.wikipedia.org/wiki/Permainan_daring.

5 "Tembak-Menembak Orang-Pertama - Wikipedia Bahasa Indonesia, Ensiklopedia Bebas," accessed November 11, 2021, https://id.wikipedia.org/wiki/Tembak-menembak_orang-pertama.
} 
stir mobil, tangan dan pemandangan dari kaca depan mobil dan seolah-olah pemain yang langsung mengemudikan balap mobil tersebut.Contoh permainan jenis ini antara lain Point Blank, Counter Strike, Quake, Blood, dsb

2. Massively Multiplayer Online Real-time strategy games (MMORTS)

Game ini menitik beratkan kehebatan pemain untuk menciptakan sebuah strategi supaya dapat mempertahankan wilayahnya dan mengalakan setiap lawannya. Ciri khas dari permainan ini adalah pemain harus mampu mengelola satu dunia maya untuk dapat menyusun satu strategi dalam menghadapai permainan dan dalam situasi apapun. Tema dalam game ini berupa sejarah (misalnya seri Age of Empires), fantasi (misalnya Warcraft), dan fiksi ilmiah (misalnya Star Wars)

3. Massively Multiplayer Online Role-playing Games (MMORPG)

Permainan ini memerankah tokoh khayalan dan berkolaborasi untuk menciptkan sebuah cerita, dan permainan ini lebih mengarah kepada kolaborasi sosial daripada untuk berkompetisi dalam memenangkan permainan. Pada umumnya para pemain dalam game ini tergabung dalam satu kelompok. Contoh dari genre permainan ini,The Lord of the Rings Online: Ragnarok Online, Shadows of Angmar, Final Fantasy.

4. Simulation games

Dalam memaikan game ini pemain bertanggung jawab untuk memaikan peran seorang tokoh dengan karakternya yang memenuhi kebutuhan tokoh tersebut layaknya seperti kehidupan nyata tetapi ini dimaikan didalam dunia maya. Dalam memaikan game ini pemain akan membuat seperti manusia secara normal dengan memenuhi kebutuhan hidupnya seperti kegiatan bekerja, bersosial, makan berbelanja dan masih banyak kegiatan lainnya layaknya manusia yang hidup. Conton dari permainan ini adalah second life. ${ }^{6}$

5. Massively multiplayer online games (MMOG)

Dalam melakukan permainan ini dapat dimaikan dalam jumlah pemain yang besar dapat dimainakan secara mendunia. Permainan ini dapat dimainkan lebih dari 100 orang pemain, dan setiap pemain dapat berhubungan satu dengan lain seperti dalam dunia nyata. MMOG ini terus mengalami perkembangan sesuai dengan perkembangan akses internet yang memungkinkan ratusan bahakan ribuah pemain dapat mekainkan game tersebut secara bersama-sama.

\section{Berdasarkan Cara Bayar}

1. Pay to Play

Agar bisa memaikan sebuah pemain online, pemain diwajibkan untuk membeli sebuah vocer atau kode permainan tersebut supaya pemain dapat memainkannya secara online. Beberapa permainan dapat di-install atau dimainkan secara gratis, namun jika seorang remaja mau menaikan tingkat level, permainan maka harus menyetor beberapa uang supaya dapat bermain. Ada beberapa aplikasi game yang dapat dilakukan secara gratis, cukup hanya menginstall aplikasinya dilaptop atau handphone dan membayar sejumlah uang diberikan pihak tertentu untuk bermain. Contohnya Ghost Online

2. Free to Play

\footnotetext{
6 “Jenis Game Berbagai Genre, Cara Main, Kelebihan Dan Kekurangan,” accessed November 11, 2021, https://telset.id/games/jenis-jenis-game-kelebihan-kekuranganya/.
} 
Dalam memaikan permainan ini pemain game tidak perlu megeluarkan uang untuk permainan ini tidak membebankan biaya kepada pemain sehingga dapat dimainkan setiap saat tanpa ada pembayaran yang dilakukan, misalnya Subspace,Travian,Terra, dan Crossfire. Ada pula permainan ebas untuk melakukan permainan tetapi diselingi oleh iklan, baik di dalam permainan atau pop-up, seperti permainan Anarchy Online.

\section{Berdasarkan Grafis}

\section{Permainan 2 Dimensi}

Dalam memaikan permainan ini sudah menggunakan teknologi dan permainan ini tidak membebani system, tetapi permainan ini belum sempurna karena memiliki kelemahan didalam tanpilan gambar yang masih buram atau kabur sehingga tidak begitu menariik dibandingkan dengan permainan yang telah menggukan 3D, tetapi kebanyakan permainan sekarang ini telah menggunakan 2,5D denggan mengabungkan 2D dan 3D karekter diambil dari permainan 2D tetapi untuk lingkungan diambil dari 3D.

\section{Permainan 3 Dimensi}

Dalam memaikan permainan 3 Dimensi akan memiliki tampilan yang lebih baik baik dalam grafik dan gambar yang lebih menyerupai akan sebenarnya ataupun nyata. Dalam memamaikan permainan ini pemaikan akan memiliki sudut pandang 360 derajat sehingga dapat melihat semua sudut dalam memaikan permainan ini, tetapi dalam memaikan permainan ini membutuhkan memori yang cukup besar agar dapat menampung permainan tersebut.

Seorang remaja yang memainkan game online baik yang dimainkan dalam sebuah komputer, handphone, tablet atau gadjet lainnya yang sudah terhubung dengan internet dapat mengakibatkan kecanduan untuk tetap bermain game. Menurut Kardefelt - Winter menyatakan bahwa kecanduan pada mulanya berkaitan dengan adanya zat adiaktif yang terdapat pada alkohol, tembakau atau obat-obat terlarang. Zat adiaktif akan masuk kedalam jaringan darah dan akan memasukim otak yang akan merubah komposisi kimia yang ada diotak, tetapi pengertian kecanduan terus berkembang bukan lagi hanya kepada penggunaan alkohol atau pada penggunaan obat-obat terlarang tetapi ini berubah kepada perilaku remaja yang terus-menerus menggunakan handphone untuk bermain game.

Menurut WHO kecanduan dalam bermain game online menyatakan bahwa kecanduan game online sebagai satu ganguan mental ${ }^{8}$. Jika anak remaja mengalami gangguan kontrol atas game dengan mengutamakan permainan game daripada kegiatan yang lain pada game maka anak tersebut sudah mengalami kecanduan terhadap game. Jika perilaku tersebut terus dilanjutkan maka akan memberikan pengaruh yang negatif terhadap dirinya sendiri.

Kecanduan dalam bermain game bagi seorang remaja dapat terlihat berapa lama mereka memegang dan memainkan game dalam hanphone mereka. Menurut Maria "anak remaja akan bermain game setiap hari 2-8 jam/hari dan ada juga anak remaja lebih dari 8 jam perhari. Remaja laki-laki akan bermain game 4-8 jam sedangkan anak perempuan 2-4

\footnotetext{
${ }^{7}$ Eryzal Novrialdy, "Kecanduan Game Online Pada Remaja: Dampak Dan Pencegahannya," Buletin Psikologi 27, no. 2 (2019): 148.

${ }^{8}$ Eryzal Novrialdy, "Kecanduan Game Online Pada Remaja: Dampak Dan Pencegahannya," Buletin Psikologi 27, no. 2 (2019): 148, https://dx.doi.org/10.22146/buletinpsikologi.47402.
} 
jam. Permainan yang sering mereka mainkan adalah free fire, Mobil legends, PUBG dan masih banyak yang lain"?.

Setiap orang yang sudah candu dalam bermain game online sering menimbulkan dampak negative atau bahaya bagi seorang remaja. Dampak kecanduan bermain game online mempengaruhi lima bagian yakni kesehatan, psikologis,akademik,sosial, dan keuangann.

\section{Dalam hal Kesehatan}

Pada waktu seorang remaja sudah candu dalam bermain game online ini akan mempengaruhi kesehatan mereka, karena dalam bermain geme mereka akan kebanyakan duduk dan kurang pergerakan hanya mata dan tangan yang bergerak dan mereka akan kurang minum dan makan dan mereka lupa untuk beristirahat dalam menyelaikan sebuah permainan.

\section{Dalam hal Psikologis}

Dengan tampilnya game online yang banyak memerakan peran dalam tindakan kriminal dan kekerasan yang secara tidak langsung jika terus menerus dimaikan akan secara tidak lamngsung akan mempengaruhi alam bawah sadar seorang remaja sehingga dalam dunia nyata mereka akan berperilaku kasar terhadap temannya. Contoh permainan yang mereka mainkan adalah berupa perkelahian, perusakan, dan pembunuhan. Pengaruh tindakan kriminal dan kekerasan yang terus disaksikan dan dimainkan sangat berbahaya bagi perkembangan psikologis seorang remaja. Anak remaja yang sudah mengalami ganguan mental disebabkan game online yakni mereka kan cepat marah karena emosi mereka yang tidak stabil dan mereka juga akan suka mengucapkan kata-kata kotor. ${ }^{10}$

\section{Dalam Hal Akademik}

Anak remaja berada pada usia sekolah yang memiliki peran sebagai siswa untuk belajar mencapai masa depan yang lebih baik. Kecanduan game oline mempengaruhi anak remaja dalam pencapaian akdemik karena waktu mereka gunakan bukan untuk belajar tetapi mereka gunakan untuk bermain game online, juga daya konsentrasi dalam belajar akan menurun karena pikiran mereka sudah tergannu untuk memikirkan permainan game yang akan mereka selesaikan, sehingga apa yang diajarkan oleh guru tidak mereka ingat. ${ }^{11}$

\section{Dalam Hal Sosial.}

Disaat anak remaja bermain game online anak remaja akan pokus kepada permainan yang dia miliki sehingga hubungannya dengan sekeitarnya hilang, dia tidak memperdulikan yang dekat dengan dia. Intraksi sosial secara online meningkat pada waktu mereka berhubungan dengan rekan mereka untuk menyelesaikan sebuah permainan. Anak remaja yang setiap saat sudah terbiasa berhubungan didunia maya akan mengalami kesulitan dalam behubungan dengan dunia nyata, karena didalam dirinya sudah terdapat satu perasaan yang tidak dapat bergaul dengan sesamanya

\section{Dalam Hal Keuangan.}

\footnotetext{
${ }^{9}$ Maria Agustina Lebho et al., "Perilaku Kecanduan Game Online Ditinjau Dari Kesepian Dan Kebutuhan Berafiliasi Pada Remaja," Journal of Health and Behavioral Science 2, no. 3 (2020): 202-212.

${ }^{10}$ Novrialdy, "Kecanduan Game Online Pada Remaja: Dampak Dan Pencegahannya."

${ }^{11}$ Stepanuston Pelawi, Stimson Hutagalung, and Rolyana Ferinia, "Pengaruh Gadget Dan Pertumbuhan Kerohanian Remaja Smp Advent Barusjulu Di Masa Pandemi Covid-19 Berdasarkan Ulangan 6:7," JURNAL KADESI 4, no. 1 (December 6, 2021): 23-45, accessed December 10, 2021, https://ejournal.sttkb.ac.id/index.php/kadesibogor/article/view/12.
} 
Dalam memaikan permainan online membutuhkan biaya agar dapat bermain secara online baik dalam membeli paket untuk internet maupun membeli vocer untuk memaikan sebuah permainan atau untuk meningkatkan level atau kemampauan dalam bermain game. Karena anak remaja belum memiki penghasilan sendiri biaya yang dibutuhkan mereka dalam bermain game biasanya mereka memintanya dari orang tua, sehingga mereka dapat melakukan kebohongan serta pencurian kepada orang tua agar mereka memperoleh biaya untuk membeli paket dan voucer dalam bermain game.

\section{Psykologi Remaja}

Masa remaja adalah masa perubahan dari anak-anak menuju dewasa. Usia remaja berlangsung antara umur 12-21 tahun. ${ }^{12}$

Masa remaja dapat dibagi menjadi :

$>$ Remaja awal berada di usia 12-15 tahun

$>$ Remaja pertengahan berada di usia 15-18 tahun

$>$ Remaja dewasa berada di usia 18-21 tahun

Pembagian lain yang sering didengar dalam masyarakat adalah:

$>$ Prapubertas yaitu masa peralihan dari masa kanak-kanak ke masa remaja berusia 1215 tahun,

> Pubertas adalah masa pemasakan seksual berusia 15-18 tahun.

$>$ Adolesensi adalah masa remaja akhir sebelum memasuki masa dewasa berusia 18-21 tahun.

Pada masa peralihan dari anak-anak kepada dewasa seorang anak akan mengalami banyak hal yang mempengaruhi pertumbuhan seorang remaja baik dari dalam diri sendiri ataupun lingkungan, karena masa remaja adalah masa:

\section{Masa remaja sebagai masa mencari identitas}

Dalam peralihan dari anak-anak menuju remaja seorang anak mulai menyusuaikan diri dengan lingkungan dan kelompok untuk dapat menunjukkan siapa dirinya yang sebenarnya. Masa remaja adalah masa mencari identitas diri untuk menyatakan siapa dirinya, apa peranan yang dapat dia laukan dalam masyarakat, apakah ia nantinya dapat menjadi seorang ayah atau ibu yang baik, atau apakah ia mampu membuat keberhasilan ataukah gagal dalam hidupnya?

Inilah masa dimana seorang anak remaja ingin menunjukan siapa dirinya kepada orang tua, sahabat dan masyarakat. Dalam hal inilah perlunya bimbingan dan arahan dari orang tua agar remaja dapat menemukan identitasnya, peranan guru juga diperlukan agar anak remaja tidak salah arah dalam menentukan teman atau sahabatnya dalam mencari identitasnya.

\section{Masa remaja sebagai masa yang labil}

Seorang remaja cenderung tidak memiliki pendirin yang tetap, mereka mudah bimbang dan mudah terikut arus dari teman-temannya. Prinsip yang mereka miliki belum kuat, prinsip yang mereka miliki adalah prinsip yang masih mudah dipengaruhi oleh teman dan sahabatnya. Anak remaja sering sekali lebih mempercayai sahabat dari pada orang tua dan guru. Dalam hal ini perlunya kedekatan antara seorang remaja dan orang tua sehingga orang tua dapat mempengaruhi anak remaja dalam pertumbuhannya dan dalam

\footnotetext{
${ }^{12}$ Riryn Fatmawaty, Fase-Fase Masa Remaja, Jurnal Reforma, vol. VI, 2017.
} 
membangun sebuah prinsip yang teguh didalam kehidupannya. ${ }^{13}$ Masa remaja juga mengalami masa pertumbuhan dan perkembangan, ini ada beberapa aspek yang sangat menonjol perkembangannya. Antara lain adalah sebagai berikut:

\section{Perkembangan Fisik}

Perkembangan dan pertumbuhan seorang anak remaja secara fisik terjadi pada usia 1217 tahun. Seorang remaja akan merasakan ketidak nyamanan dalam dirinya karena adanya perobahan dan pertumbuhan anggota badan dan otot-otot secara tidak seimbang. Pertumbuhan otak seorang anak terjadi pada usia 10-13 tahun bagi anak perempuan dan bagi anak laki-laki 14 - 17 tahun. Pertumbuhan otak anak perempuan terjadi secara siknifikan terjadi pada usia 11 tahun sedangkan bagi anak laki-laki perumbuhan otak secara siknifikan terjadi pada usia 15 tahun dimana pada masa ini pertumbuhan otak meningkat duakali lipat dibandingkan dengan anak perempuan. ${ }^{14}$

\section{Perubahan Internal}

Pertumbuhan dan perkembangan remaja secara internal meliputi:

a. Sistem Pencernaan

Perubahan dalam system pencernaan mulai mengalami perubahan dimana perut akan mengalami perkembangan menjadi lebih panjang dan juga hati akan mengalami pertambahan berat demikian juga kerongkongan akan bertambah panjang. Otot-otot yang ada didalam perut daan juga dingding-dingding usus seseorang mejadi lebih tebal dan lebih kuat. Usus-usu tersebut akan mengalami pertumbuhan bertambah panjang dan bertambah besar.

b. Dalam system peredaran darah juga mengalami perubahan dimana system peredaran darah yang berperan penting adalah jantung yang mengalami pertumbuhan yang siknifikan pada saat remaja berusia 17-18 tahun dimana besar jantung akan mencapai 12 kali lipat beratnya dibandingkan pada waktu seseorang lahir. Panjang dan tebal dingding pada pembuluh dara akan mencapai kesempurnaan pada waktu jantung sudah sempurna.

c. Dalam perubahan jaringan tubu, kerangka manuasia yang menopang tubuh seseorang akan mengalami pertumbuhan sampai usia 18 tahun, sedangkan untuk jaringan tulang akan terus mengalami perkembangan sampai ukuran kesempurnaan dalam diri seseorang.

d. Dalam system pernapasan yakni kapasitas paru-paru untuk anak perempuan akan mengalami kesempurnaan pada usia 17 tahun sedangkan bagi anak laki-laki system pernafasannya akan menjadi sempurna beberapa tahun kemudian.

\section{Perkembangan Emosi}

Seorang anak remaja akan memiki emosi yang tinggi dibandingkan dengan seorang anak-anak, ini disebabkan mereka sedang berada dibawah tekanan sosial dari sekelingling mereka, dan mereka sedang beradaptasi dengan satu perubahan dalam lingkungan. Dan penyebab seorang remaja memiliki emosi yang tinggi karena mereka tidak mempersiapkan diri mereka untuk dapat bergaul dalam kehidupan masyarakat yang baru. Menurut Abu Ahmadi dan Munawar Sholeh bahwa kesempurnaan emosi anak lelaki dan anak perempuan

\footnotetext{
${ }^{13}$ Dr. Sri Wahyuni, "PSIKOLOGI REMAJA: PENANGGULANGAN KENAKALAN REMAJA Dr. Sri Wahyuni, M. Th - Google Books."

${ }^{14}$ Fatmawaty, Fase-Fase Masa Remaja, vol. VI, p. .
} 
akan terlihat ketikan mereka dihadapkan dalam sebuah perrmasallahan, dan dalam menghadapi permasallah tersebut bagaiman mereka dapat mengendalikan emosi mereka dihadapan orang banyak dan bagaiman cara mereka menumpahkan emosi mereka dengan cara yang dapat diterima secara logika. ${ }^{15}$

\section{Perubahan Eksternal}

Pertumbuhan secara fisik bagi anak perempuan dalam hal tinggi badan akan mencapai kesempurnaan pada usia 17-18 tahun, sedangkan pertumbuhan fisik bagi anak laki-laki akan mengalami 1 tahun keterlambatan dari anak perempuan. Untuk perubahan dalam berat badan akan mengikuti perubahan secara fisik dalam tinggi badan, tetapi berat badan juga tergantung kepada banyaknya makanan yang dikomsumsi anak remaja yang mengakibatkan adanya pertambahan lemak didalam daging. Sedangkan untuk organ seks akan mengalami kesempurnaan pada akhir masa remaja. Organ sek pada wanita akan lebih cepat berkembang pada wanita dibandingkan pada pria.

Untuk bentuk tubuh: ada beberapa bagian tubuh yang akan mengalami pertumbuhan yang lambat seperti adanya bagian badan yang semakin melebar atau gemuk yang mengakibatkan sesorang kelihatan akan lebih pendek buka pertumbuhan kearah tinggi badan.

\section{Perkembangan pengetahuan}

Dalam perkembangan pengetahuan tidak terlepas dari pertumbuhan otak seseorang. Perkembangan otak manusia akan mencapai kesempurnaan pada saat seseorang mencapai usia 12 tahun. Dimana system saraf yang bekerja untuk memproses infomasi telah berkembang dengan cepat dan telah membuat pengorganisasian kembali lingkaran sarat yang terdapat pada otak bagian depan yang kemudian akan berfungsi untuk dapat membuat sebuah rencana atau strategi dalam memutuskan sesuatu permasallahn dan juga untuk mengambil sebuah keputusan dalam sebuah kegiatan atau dalam menghadapi satu keadaan.

\section{Perkembangan Sosial}

Perkembangan sosial dapat terjadi jika seseorang sudah mampu memahami orang lain. Seorang remaja yang berkembang di dalam sosial akan mudah untuk memahami keadaan orang lain dimana setiap manusia akan memiliki keunikan tersendiri, karena sifat setiap manusia berbeda satu dengan yang lain. Jika seorang remaja sudah dapat memahami orang lain yang disekitarnya maka dia akan memiliki hubungan yang akarab dalam menjalin hubungan sosial dengan satu dan yang lainnya terutama teman yang seusia dengan dia.

Melihat dari perkembangan psykologi ramaja yang masih mudah terpengaruh dengan keadaan dan lingkungan, apabila mereka ditawarkan kepada sebuah permainan game maka mereka akan mudah terpengaruh untuk memainkan game tersebut karena rasa ingin tahu anak remaja sangat tinggi yang kemudian membuat mereka akan menjadi candu untuk bermain game.

Untuk mengatasi permasalah tersebut diperlukan peranan orang tua dan guru agama pendidikan agama Kristen untuk memberikan bimbingan dan konsling bagaimana seorang remaja harus menjaga hatinya. Dalam Amsal 4:23 "Peliharalah hatimu dengan segala

\footnotetext{
${ }^{15}$ Komarudin, "Membentuk Kematangan Emosi Dan Kekuatan Berpikir Positif Pada Remaja Melalui Pendidikan Jasmani,” Jurnal Pendidikan Jasmani Indonesia 12, no. 2 (2016): 67-75. 
kewaspadaan karena dari sanalah pancaran kehidupan"16 frasa "menjaga hati"17 sama dengan berjaga-jagalah dengan segala kewaspadaan supaya jangan jatuh kedalam pencobaan sehingga terhindar untuk melakukan hal-hal yang negatif.

Jagalah dan berjaga-jagalah adalah satu perintah yang Tuhan berikan bagi setiap orang didalam dunia, khusunya bagi anak remaja didalam kehudupannya, karena lukas 21:34 juga menyebutkan "jagalah dirumu supaya hatimu jangan sarat oleh pesta pora dan kemabukan" Allah mengharapkan agar anak remaja dapat menjaga hati yang dapat sisebut dengan fikiran untuk takut kepada Tuhan dan didalam ayat 36 disebutkan "berjaga-jagalah sambil berdoa". Allah mengharapkan agar anak remaja setiap saaat mengambil waktu untuk bersekutu dengan Tuhan sehingga sanggup mengalahkan pencobaan yang datang kepadanya.

Melihat bagaimana pentingnya remaja untuk menjaga hati atau pikiran dari hal-hal yang negative yang dapat dipengaruhi dari game online yang menimbulkan hal yang buruk maka perlu diadakan pendekatan dan pendampingan kepada remaja agar mereka dapat mengarahkan hati mereka kepada hal-hal yang baik yang sesuai dengan firman Tuhan.

Dari pengamatan yang dilakukan kepada beberapa remaja yang bersekolah di SMP Advent Barusjulu didapati ada 28 anak remaja yang mengalami masalah karena bermain game online. Remaja yang sering bermain game secara online didapati adanya penurunan:

- Di bidang akademik terlihat dari penurunan pencapaian dalam belajar karena keinginan mereka untuk bersekolah menurun terlihat dari tugas mereka yang tidak diselesaikan dan selama mengikuti pelajaran di dalam kelas tidak ada semangat dalam belajar

- Di dalam hal kesehatan terlihat mata mereka yang sayu karena terlalu lama memperhatikan layar handphone dan saat belajar di kelas mereka lemas mengakibatkan konsentrasi dalam belajar dalam belajar berkurang.

- Di dalam psykologis anak adanya perubahan karena tidak dapat bersahabat dengan baik terhadap teman sebayanya dan sering terlihat prilaku yang kasar yang ditimbulkan terhadap temannya.

Agar remaja mengarahkan hati mereka kepada hal-hal yang baik terhindar dari kecanduan bermain game online dapat dilakukan beberapa upaya dilakukan untuk mencegah remaja mengalami kecanduan dalam bermain game online

Tindakan pencegahan yang dilakukan adalah bertujuan untuk menghalangi dan menghindari kondisi yang tidak kita inginkan kepada anak remaja, kaarena mencegah sebuah masallah lebih baik daripada mengobati dan meneyelesaikan satu masallah yang sebenarnya masih dapat dihindari. Upaya yang dapat dilakukan dalam pencegahan diantaranya adalah a. menghentikan perilaku yang bermasalah sebelum hal itu terjadi dan $b$. menunda timbulnya prilaku yang bermasallah dengan keterlibatan orang tua, guru dan memberikan pendampingan bagi anak remaja

\footnotetext{
16 “Amsal 4:23 (Versi Paralel) - Tampilan Ayat - Alkitab SABDA,” accessed November 11, 2021, https://alkitab.sabda.org/verse.php?book=ams\&chapter=4\&verse=23.

${ }^{17}$ Benjamin Pintakhari, "Makna Frasa 'Jagalah Hatimu' Menurut Amsal 4:23," ILLUMINATE: Jurnal Teologi dan Pendidikan Kristiani 3, no. 1 (2020): 61-69.
} 


\section{Menghentikan Perilaku Bermasalah Sebelum Terjadi}

Mencegah lebih baik dari pada mengobati, sebelum remaja menjadi kecanduaan bermain game online perlu diberikan pendidikan khusunya bagaimana menggunakan handpon bagi remaja, hal ini dapat dilakukan terlebih dahulu dengan mengadakan konsultasi dengan orang tua tentang penggunaan handphon yang benar bagi seorang remaja.

Konsling yang dapat dilakukan dilakukan oleh guru Pendidikan Agama Kristen kepada orang tua ialah dengan menyatakan bahwa yang memberikan handphone kepada anak remaja adalah orang tua sehingga yang memiliki peran yang pertama dalam mengawasi anak remaja adalah orang tua, karena pendidikan rumah tangga adalah pendidikan yang pertama bagai seorang anak. ${ }^{18}$

Dengan pemahaman yang benar dari orang tua bagaimana besarnya pengaruh game online terhadap remaja, sehingga dengan konsling yang diberikan kepada orang tua dapat memberikan perubahan cara pendidikan orang tua kepada anak.

Sekolah juga memiliki perana untuk mengarahkan remaja agar tida bermain game online yaitu dengan mengalihkan perhatian remaja dari keterlibatan yang berlebihan terhadap game online dapat dilakukan dengan melibatkan anak remaja dalam kegiatan fisik yang membuat mereka melupakan permaina game online.

Tindakan yang dapat dilakukan sekolah dalam kegiatan fisik adalah mengajak anak remaja untuk mengikuti kegiatan ekstrakurikuler seperti kegiatan Pramuka, Musik dan olah raga. Kegiatan fisik seperti olah raga akan membuat anak remaja lipa un tik meaikan game online mereka karena mereka pokus kepada kegiatan yang mereka ikuti, dan jika ini terus dilakukan mereka akan melupakan game mereka dan ketika guru pembimbing dapat mengarahkan mereka kepada bakat yang mereka miliki mereka akan meninggalkan game online mereka.

\section{Menunda Timbulnya Perilaku Masalah}

Untuk dapat menunda atau tidak terjadinya satu masallah dapat dilakukan dengan memberikan pendidikan atau pengarahan kepada anak remaja, khusunya pengarahan penggunaan handphon dan pengaruh yang ditimbulkan jika seorang anak remaja tidak dapat mengontrol dirinya dalam bermain game online.

Sekolah mempunyai peranan dalam menunda timbulnya perilaku yang bermasallah bagi anak remaja. Sekolah dapat memberikan pemahaman melalui seminar bagaimana prilaku yang postif yang dapat dilakukan seorang ramaja dalam menggunakan handphon dan apa akibat jika remaja sudah kecanduan dalam bermain game online, upaya yang dibuat sekolah untuk mencegah perilaku untuk kecanduan bermain game online adalah tidakan efektif dan efisien karena hal dilakukan sebelum anak remaja mengalami kecanduan game online. Berdasarkan hasil wawancara dengan beberapa orang tua dan remaja yang ada di SMP Advent Barusjulu ditemukan bahwa masih ada 28 remaja yang belum memiliki pemahaman yang memadai mengenai bahaya kecanduan game online. Pemahaman bahaya dalam kecanduan bermain game online sangat penting bagi seorang remaja karena ini akan memberikan bagi dia sebuah pertimbangan dalam memainkan game dan mereka dapat mengambil keputusan untuk meninggalkan permainan game.

${ }^{18}$ Ellen G. White, Membina Anak Yang Bertanggung Jawab (Indonesia Publising House, 2005), accessed August 18, 2021, 5. 
Dari hasil konsling dan pendampingan yang dilakukan kepada beberapa anak remaja di SMP Advent Barusjulu ditemukan bahwa ada perubahan yang terjadi kepada anak yang sudah mengetahui apa dampak buruk jika terus bermain game online, terlihat bagaimana kehadiran mereka dalam pembelajaran baik secara oline maupun tatap muka dan juga mereka sudah menyelesaikan tugas yang telah diberikan oleh guru kepada mereka, tetapi ini semua tidak terlepas juga dari dukungan orang tua kepada anak remaja.

Orang tua memiliki peran penting ${ }^{19}$ dalam mencegah prilaku meyimpang bagi anak remaja khusunya dalam kecanduan game online, karena yang menyediakan handphon bagi anak remaja adalah orang tua. Penelitian yang dilakukan Van den Eijden dan temantemannya memberikan bukti bahwa adanya komunikasi yang baik antara orang tua dan anak remaja akan mencegah anak remaja dalam kecanduan bermain game online, karena orang tua telah memberikan pemahaman yang baik bagimana menggunakan handphon. ${ }^{20}$

Jika orang tua tidak memberikan komunikasi yang baik bagi anak remaja dan tidak adanya pengawasan hal inilah yeng membuat anak remaja akan cendrung untuk terus bermain game secara online karena buruknya hubungan orang tua dan anak remaja. Perhatian orang tua kepada anak remaja dalam bermain game online adalah sebuah tindakan pencegahan terhadap kecanduan game online. Orang tua juga harus berhati-hati dalam memberikan aksek kepada anak mereka karena dengangan adanya perkembangan teknologi handphon yang diberikan orang tua kepada anak remaja adalah sarana untuk bermain game online. Orang tua perlu setiap saat mengadakan pemantuan tehadap anakanak mereka apa yang mereka lakukan didalam handphon mereka. ${ }^{21}$

Anak remaja yang sudah kecanduan dalam bermain game online mere menganggap bahwa masa depan mereka ada dalam dunia geme, sehingga mempengaruhi mereka dalam aktivitas lainnya. Hal inilah yang membuat perlunya komunikasi yang baik antara orang tua dan anak remaja dan perhatian dari orang tua agar anak remaja dapat mengetahui apa yang terbaik yang mereka lakukan di dlam handphon yang telah diberikan orang tua bagi mereka. Jika ini terus dilakukan orang tua maka anak remaja akan terhindar dari kecanduan bermain game online 22

Dengan adanya kemajuan teknologi yang terus berkembang anak remaja dengan mudah untuk mengakses permaina yang mereka inginkan, jika tidak ada pengawasan dan perhatian dari orang tua seorang anak akan cendrung memaikan game mereka lebih sering dan lebih lama, jika anak tersebut berada dalam kamar dimalam hari mereka akan tidur pada waktu tengah malam karena bermain game dan waktu istirahat mereka akan lebih sedikit dan ketika mereka melakukan aktifitas di sianga hari mereka tidak akan konsentrasi dalam melaukan pekerjaan mereka

${ }^{19}$ Elieser R Marampa, "Peran Orangtua Dan Guru Pendidikan Agama Kristen Dalam Membentuk Karakter Kerohanian Peserta Didik," SESAWI: Jurnal Teologi dan Pendidikan Kristen 2, no. 2 (2021): 100115.

${ }^{20}$ Novrialdy, "Kecanduan Game Online Pada Remaja: Dampak Dan Pencegahannya."

${ }^{21}$ Erni Hanna Nadeak, "Karakteristik Pendidikan Yang Menebus Di Suatu Sekolah Kristen [The Characteristics of Redemptive Education In a Christian School] | Nadeak | Polyglot: Jurnal Ilmiah," Universitas Pelita Harapan (2017): 87-98.

${ }^{22}$ Ari Kusuma Sulyandari, "Pengaruh Gadget Pada Perkembangan Anak Usia Dini," THUFULI :Jurnal Pendidikan Islam Anak Usia Dini I, no. 1 (2019): 12-20. 
Untuk dapat menunda terjadinya kecanduan game bagi anak remaja peran yang telah dilakukan sekolah adalah dengan menjalin kerjasama dengan orang tua peserta didik. Orang tua dipanggil kesekolah dan juga anak yang bermasallah dalam hal game online dan diberikan penjelasan kepada orang tua bahwa orang tua sangat berperan penting dalam mengawasi anak-anak selama belajar dirumah. Sekolah juga memberikan pengertian bahwa handphon yang dimilkiki anak tidak selamanya harus mereka yang pegang tetapi orang tua dapat memberikan displin waktu bagi anak mereka dalam mempergunakan handphon agar tidak banyak waktu yang mereka gunakan untuk bermain game

\section{KESIMPULAN}

Dengan adanya game online sangat berpengaruh kepada perkembangan remaja, sehingga perlu perhatian dan bimbingan dari orang tua dan guru untuk memberikan pengertian dan pemahaman dampak negatif dari bermain game online. Orang tua harus mengajarkan kepada anak remaja perlunya menjaga hati dari hal-hal yang tidak baik agar masa depan mereka akan lebih baik dan mereka akan memiliki kesehatan yang sempurna. Jika anak remaja terus bermain game online maka akan mempengaruhi dalam pertumbuhan baik secara fisik dan psykologis anak remaja yang mengakibatkan karena game online akan mempengaruhi:

Aspek kesehatan remaja akan terganggu karena waktu yang mereka gunakan dalam bermain game membuat mereka lupa untuk makan dan minum dan juga kurangnya waktu istirahat pada malam hari

Aspek psikologis remaja akan terganggu karena melihat permainan perang dan pembunuhan yang mempengaruhi psykologi remaja

Aspek akademik remaja akan menurun karena waktu yang seharusnya mereka gunakan belajar meguka gunakan untuk bermain game

Aspek sosial remaja semakin berkurang karena hanya duduk dengan memegang handphon ditangaan tanpa ada pergaualan dengan teman-teman sebaya di lingkungannya Aspek keuangan remaja akan terganggu karena uang yang mereka miliki mereka gunakan untuk membeli pulsa dan vocer untuk bermaain game.

Jadi game onli sangat berbahaya bagi remaja jika tidak ada pengarahan dari orang tua dan guru.

\section{DAFTAR PUSTAKA}

Dr. Sri Wahyuni, M. Th. "PSIKOLOGI REMAJA: PENANGGULANGAN

KENAKALAN REMAJA - Dr. Sri Wahyuni, M. Th - Google Books.” Accessed

September 29, 2021.

https://books.google.co.id/books?hl=en\&lr=\&id=QGtAEAAAQBAJ\&oi=fnd\&pg=PA

$1 \& d q=$ psikologi+remaja\&ots=pglNM3QYGd\&sig=K3_FO9IDJUJUa-

qsYmcFvfsUM5A\&redir_esc=y\#v=onepage $\& \mathrm{q}=\mathrm{psikologi}$ remaja $\& \mathrm{f}=$ false.

Fatmawaty, Riryn. Fase-Fase Masa Remaja. Jurnal Reforma. Vol. VI, 2017.

Komarudin. "Membentuk Kematangan Emosi Dan Kekuatan Berpikir Positif Pada Remaja

Melalui Pendidikan Jasmani." Jurnal Pendidikan Jasmani Indonesia 12, no. 2 (2016):

$67-75$.

Lebho, Maria Agustina, M. Dinah Ch. Lerik, R. Pasifikus Christa Wijaya, and Serlie K. A. Littik. "Perilaku Kecanduan Game Online Ditinjau Dari Kesepian Dan Kebutuhan 
Berafiliasi Pada Remaja." Journal of Health and Behavioral Science 2, no. 3 (2020): 202-212.

Marampa, Elieser R. "Peran Orangtua Dan Guru Pendidikan Agama Kristen Dalam Membentuk Karakter Kerohanian Peserta Didik.” SESAWI: Jurnal Teologi dan Pendidikan Kristen 2, no. 2 (2021): 100-115.

Nadeak, Erni Hanna. "Karakteristik Pendidikan Yang Menebus Di Suatu Sekolah Kristen [The Characteristics of Redemptive Education In a Christian School] | Nadeak | Polyglot: Jurnal Ilmiah." Universitas Pelita Harapan (2017): 87-98.

Novrialdy, Eryzal. "Kecanduan Game Online Pada Remaja: Dampak Dan Pencegahannya." Buletin Psikologi 27, no. 2 (2019): 148.

_ . "Kecanduan Game Online Pada Remaja: Dampak Dan Pencegahannya." Buletin Psikologi 27, no. 2 (2019): 148. https://dx.doi.org/10.22146/buletinpsikologi.47402.

Pelawi, Stepanuston, Stimson Hutagalung, and Rolyana Ferinia. "Pengaruh Gadget Dan Pertumbuhan Kerohanian Remaja Smp Advent Barusjulu Di Masa Pandemi Covid-19 Berdasarkan Ulangan 6:7." JURNAL KADESI 4, no. 1 (December 6, 2021): 23-45. Accessed December 10, 2021. https://ejournal.sttkb.ac.id/index.php/kadesibogor/article/view/12.

Pintakhari, Benjamin. "Makna Frasa 'Jagalah Hatimu' Menurut Amsal 4:23,., ILLUMINATE: Jurnal Teologi dan Pendidikan Kristiani 3, no. 1 (2020): 61-69. Sinaga, Janes, Rudolf Weindra Sagala, Rolyana Ferinia, and Stimson Hutagalung. "Peran Fundamental Gembala Bagi Guru Saat Pandemik Dalam Pembelajaran Online Berbasis Karakter: Tantangan Dan Sistem Pendukung." Jurnal Pendidikan Agama Kristen (JUPAK) 2, no. 1 (December 3, 2021): 13-35. Accessed December 10, 2021. https://ejurnal.sttkadesiyogyakarta.ac.id/index.php/jupak/article/view/61.

Sulyandari, Ari Kusuma. "Pengaruh Gadget Pada Perkembangan Anak Usia Dini." THUFULI : Jurnal Pendidikan Islam Anak Usia Dini I, no. 1 (2019): 12-20.

Surya Dharma, MPA., Ph.D. "Pendekatan, Jenis, Dan Metode Penelitian Pendidikan" (2008).

White, Ellen G. Membina Anak Yang Bertanggung Jawab. Indonesia Publising House, 2005. Accessed August 18, 2021. 5.

“Amsal 4:23 (Versi Paralel) - Tampilan Ayat - Alkitab SABDA.” Accessed November 11, 2021. https://alkitab.sabda.org/verse.php?book=ams\&chapter=4\&verse $=23$.

"Jenis Game Berbagai Genre, Cara Main, Kelebihan Dan Kekurangan.” Accessed November 11, 2021. https://telset.id/games/jenis-jenis-game-kelebihan-kekuranganya/. "Permainan Daring - Wikipedia Bahasa Indonesia, Ensiklopedia Bebas." Accessed November 11, 2021. https://id.wikipedia.org/wiki/Permainan_daring.

"Tembak-Menembak Orang-Pertama - Wikipedia Bahasa Indonesia, Ensiklopedia Bebas." Accessed November 11, 2021. https://id.wikipedia.org/wiki/Tembakmenembak_orang-pertama. 